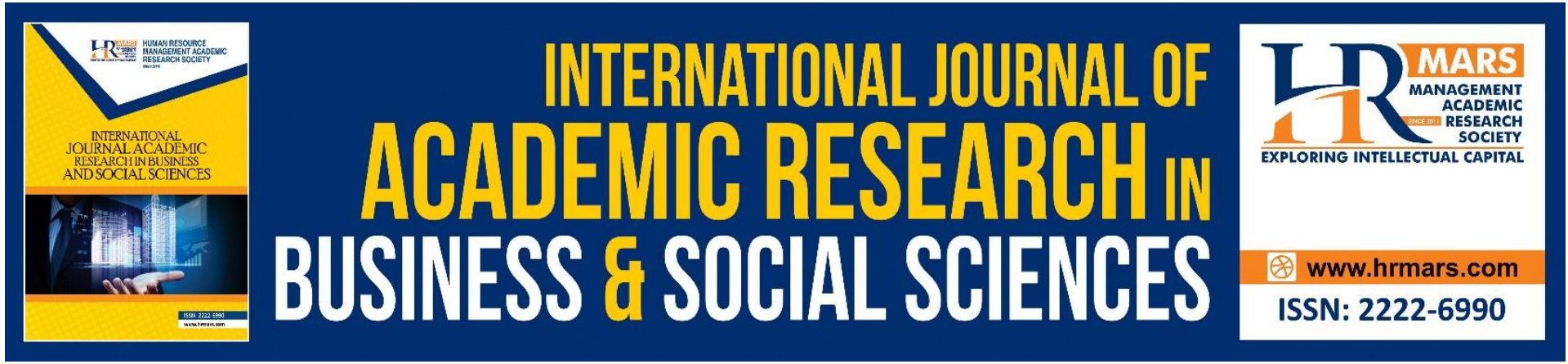

\title{
Technology -Based Support in Organizations and the Impact on Affective Commitment
}

Nor Azima Ahmad, Fariza Md Sham, Azman Ismail

To Link this Article: http://dx.doi.org/10.6007/IJARBSS/v11-i8/9938

DOI:10.6007/IJARBSS/v11-i8/9938

Received: 15 June 2021, Revised: 19 July 2021, Accepted: 07 August 2021

Published Online: 25 August 2021

In-Text Citation: (Ahmad et al., 2021)

To Cite this Article: Ahmad, N. A., Sham, F. M., \& Ismail, A. (2021). Technology -Based Support in Organizations and the Impact on Affective Commitment. International Journal of Academic Research in Business and Social Sciences, 11(8), 1263-1274.

Copyright: (c) 2021 The Author(s)

Published by Human Resource Management Academic Research Society (www.hrmars.com)

This article is published under the Creative Commons Attribution (CC BY 4.0) license. Anyone may reproduce, distribute, translate and create derivative works of this article (for both commercial and non-commercial purposes), subject to full attribution to the original publication and authors. The full terms of this license may be seen at: http://creativecommons.org/licences/by/4.0/legalcode

Vol. 11, No. 8, 2021, Pg. 1263 - 1274

http://hrmars.com/index.php/pages/detail/IJARBSS

JOURNAL HOMEPAGE

Full Terms \& Conditions of access and use can be found at http://hrmars.com/index.php/pages/detail/publication-ethics 


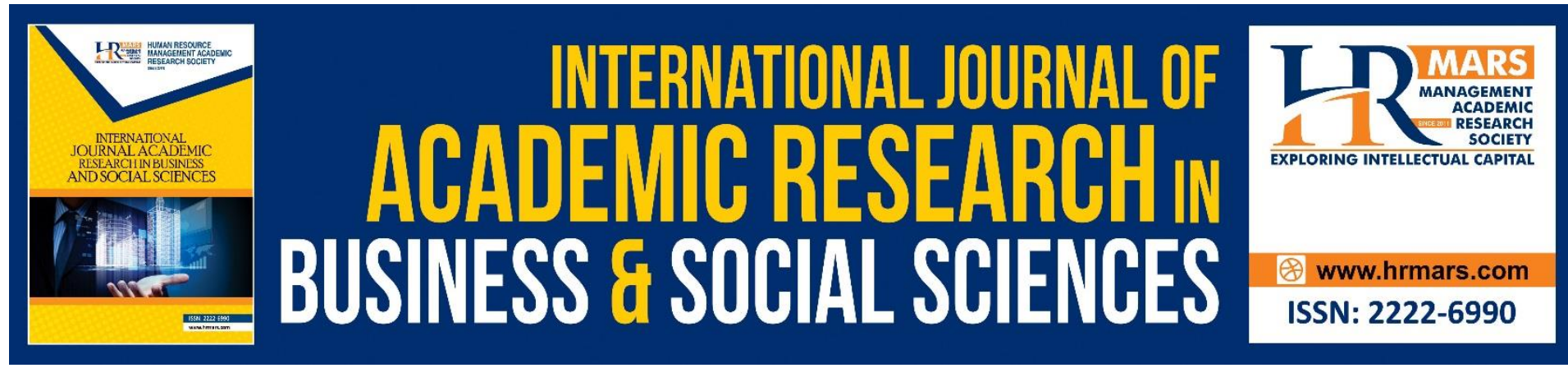

\title{
Technology -Based Support in Organizations and the Impact on Affective Commitment
}

\author{
Nor Azima Ahmad \\ Institut Islam Hadhari, Universiti Kebangsaan Malaysia \\ Fariza Md Sham \\ Institut Islam Hadhari, Universiti Kebangsaan Malaysia \\ Faculty of Islamic Studies, Universiti Kebangsaan Malaysia \\ Azman Ismail \\ Institut Islam Hadhari, Universiti Kebangsaan Malaysia \\ Email: norazimaa@gmail.com
}

\begin{abstract}
Pandemic covid-19 has increased organizational management's dependence on technology and online support to ensure the organizations' sustainability and execution of operation. This study tested the extent to which support from supervisors and colleagues in adapting technology can increase employee affective commitment to the organization. Data were collected using purposive sampling technique by distributing 250 questionnaires to respondents working in government institution in Malaysia. Smart-PLS software was used to analyze the measurement and structural of the model. The results of the study showed that supervisor support and peer support had a positive relationship with affective commitment in organization. The commitment from the employee able to drive the organization in achieving its vision and objective.
\end{abstract}

Keywords: Support, Affective Commitment, Smart-PLS

\section{Introduction}

In the current era of globalization, there is several ways organization should care and maintaining the welfare of employees to prevents increased turnover intentions among employees and increases employee commitment to the organization especially support from organization (Eisenberger et al. 2008). Organizations nowadays need to spend huge funds on training employees in order to increase their skills and knowledge (Jehanzeb \& Bashir, 2013). Thus, it is important for the organization to ensure that every trained employee is committed to the task and the organization through providing enough support to the employees (Colakoglu et al., 2010; Uzun, 2018).

The use of technology and online support began to increase after the world was hit by the Covid-19 pandemic (Ting et al., 2020). To prevent and stop the chain of Covid-19, most 
countries have issued instructions to work from home, including Malaysia with the issuance of the Movement Restrict Order (Daniel, 2020). The implementation of work from home is carried out in ensuring that social incarceration and epidemic prevention are emphasized to all communities, the Malaysian government must also ensure that economic activities run as usual to maintain stabil the economic. (Daniel, 2020). Work from home defined as working from home or other location provided by the organization (Reshma et al., 2015; Raisiene et al., 2020). In other word, work from home enabling employees fulfill their work obligations under any circumstances.

Industrial Revolution 4.0 (IR 4.0) which is technological transformation help and guide the organizations to continue its operation with the use of technological equipment and software in launching and facilitating human resource management operations (Rabeh Morrar et al., 2017). IR 4.0 concept is the structuring between humans, objects and systems in real time (Bayraktar \& Atac, 2018). The management of organization mostly uses the concept of the internet as an object of management and virtual reality. The internet is a very important communication intermediary object in facilitating our daily lives (Bayraktar \& Atac, 2018). In addition, the key feature for IR 4.0 is virtual reality that is live, direct and indirect imaginary enriched by computer to generated sound, image, graphics (Bayraktar \& Atac, 2018). Most of the communications, meetings, conferences and operations with the concept of internet and virtual reality are conducted using Zoom software, WhatsApp, Microsoft team and Google Meet due to Covid-19 (Mobo \& Abdul Rahmat, 2021). The internet user statistics released by the Malaysian Communications and Multimedia Commission (MCMC, 2020) Department of Behavior and Statistics shows that $88.7 \%$ of the population are internet users and the smartphone is the most popular device with a saturation usage level of $98.7 \%$ in 2020 .

Supervisor and colleague support is an element of management support or perceptions of organizational support (Eisenberger, 2002; Ahmed et al., 2011). Perceived organizational support defined as a perception of employees towards the organization on how much the organization care and acknowledge their contribution (Eisenberger et al., 1986; Kurtosis et al., 2015; Ahmad et al., 2021). The readiness of the supervisor and colleague to share knowledge, cooperate in job execution as a team, good communication and relationship will create a comfortable and effective working environment which increase employee performance and positive behavior (Ahmad et al., 2021; Ogbodoakum et al., 2020). A review of the literature from previous studies related to perceived organizational support shows that the effectiveness of support practices in the organization will benefit the organization, namely employee performance, organizational commitment and positive employee behavior (Kurtosis et al., 2015; Colakoglu et al., 2010; Putri et al., 2018; La Husen et al., 2019). Roochmi \& Hidayat (2018), Tajuddin et al. (2019) and Colakoglu et al. (2010) states that affective commitment is defined as the emotional attachment, and involvement that employees have for their organization.

The importance of technology and the increase in internet users shows that organizations must take proactive steps by providing internet networks, technology equipment and technology such as a computer, tablets, mobile devices to employees to ensure that each employee is able to compete with current technological developments in ensuring employee commitment to work as well as technological training to the employees to adopt digital tools 
and to ensure that the organization can operate smoothly (Wayne et al., 2016; Pfano \& Beharry, 2016).

The practices of support behavior among employees in an organization is important in ensuring the organization can function smoothly to achieve the organization objectives (Ida Rosnita et al., 2018). Past studies shows that supervisor support and colleagues support can increase employee affective commitment. Study from Juraifa \& Mafuzah (2013) stated that supportive practices will provide a strong association between employees and the organization in which employees will influence employee behavior including commitment. This study is supported by (Kaur \& Aneet, 2017) and (Andini \& Parahyanti, 2019) who explain that organizations that take care of the welfare and well -being of employees by providing effective support to employees can increase employee affective commitment. A study from Ahmad et al. (2019) explains in detail about supervisor and co-worker who have a good relationship will increase the obligation and commitment towards organization as they trust and help each other. Supervisor can enhance the support practices among employee by adopting knowledge sharing, opportunities to give opinion and care about employee wellbeing (Rabbani et al., 2017; Ahmad et al., 2021)

IR 4.0 ensure the sustainability of the organization in a global world by using advances technology which allows faster data interpretation and accurate procedure (Sima et al., 2020). IR 4.0 can benefit the organization in many ways such as productivities, increase the profitability, and increase the organization's competitiveness and sustainability in global industry (Morrar et al., 2017; Yahaya et al., 2018; Sima et al., 2020). Hence, from the above explanation, by giving an employee's adequate cohesive support such as providing a modern and digital tool can help employee to fulfill the duties when they can receive a clear job instruction, can communicate regularly with their supervisor and co-worker and receive fast feedback amid pandemic of Covid-19 situation. These modern and digital tools can help employees to stay focus and increase the sense of attachment and emotion to work towards the organization by giving full commitment to the tasks even though employee work from home and lack of supervision from leaders. This situation may lead to increase organization performance (Ibrahim et al., 2020)

The objective of this study was to measure the relationship between supervisor support and affective commitment and to measure the relationship between peer support and affective commitment.

\section{Organizational Support Theory}

This study is in line with organizational support theory (Eisenberger, 1986). Eisenberger et al. (1986) stated that when employee socio-emotional are met with their expectation and perception which the organization acknowledge their contribution and care about their wellbeing, the employees will increase their motivation, performance, obligation into work and most importantly increase their affective commitment.

According to organizational support theory, employees tend to view human-like characteristics to organization. Since supervisors and co-workers are viewed as organizational agents, sufficient support from supervisors and co-worker will increase affective commitment and employee behavior (Ahmed et al., 2011). Employee's perception is based on the 
organization policies, norms and culture which affect their judgment on how much the organization care about them (Eisenberger et al., 1986). Based on this principle, employee perception will positively increase if employees view organizational rewards and favorable job conditions such as pay, promotions, job enrichment, and influence over organizational policies as voluntary behaviors of organizations (Eisenberger et al., 1986). Based on organizational theory (Eisenberger et al., 1986), researcher develop two hypotheses in this study:

H1: supervisor support positively significant with affective commitment

$\mathrm{H} 2$ : co-worker support positively significant with affective commitment

\section{Methodology}

\section{Unit Analysis and Sampling}

Cross-sectional design is use in this research. According to Cresswell (2008) and Sekaran \& Bougie (2010), this method is commonly use because researcher can collect more accurate data, improve the quality of the data collected and can avoid bias elements. Unit analysis in this study is employees who work at government institution in Malaysia. The purposive sampling method was used to collect the data from February 2020 to October 2020. A purposive sampling method was chosen because the management could not provide a list of respondents to the researcher due to the organizations adopt a confidentiality policy. This situation does not allow researchers to select respondents using random sampling methods. Minimum sample size determined using the G*Power software (Erdfelder et al., 1996). Minimum sample size of this study is 43 respondents. The sample in this study is 250 respondents which conclude that the minimum sample required is achieved.

\section{Data Analysis}

The Smart-PLS version 3.3 software was used to determine the validity and reliability of the instrument and test the research hypotheses (Henseler et al., 2009; Ringle et al., 2015; Hair et al., 2017). The statistical package provides many advantages, which includes providing latent variables scores, avoiding small sample size problems, estimating complex models with many latent and manifest variables and error terms, and handling both reflective and formative measurement models (Henseler et al., 2009).

SPSS version 26.0 was used to cleaning the data and analyze descriptive analysis. After data was cleaning and screening, measurement model analysis was done using Smart-PLS to determine the validity and the reliability. In term of validity and reliability, factor loadings value must be greater than 0.708 . For convergent validity Variance Inflation Factor (VIF) value must be below than 5.0 to indicate that there is no collinearity issue between variables in this study. Cronbach Alpha (CA) and Composite Reliability (CR) value must be greater than 0.7 (Hair et al.2007), Average Variance Extract (AVE) must greater than 0.5 (Fornell \& Lacker, 1981). Moreover, for discriminant validity, the heterotrait-monotrait ratio of correlations (HTMT) value must be lower than 0.85 (Hair et al., 2017).

Structural model analysis was done after the validity and reliability was measured. Bootstrapping was used to analyze structural model to test hypotheses in this study. For one tail $90 \%$ significance level, the value of $t$-statistics must be greater than 1.28 . The effect size $\left(f^{2}\right)$ of the independent variable in the research model based on criteria suggested by Hair et 
al. (2017) and Henseler (2010). 0.02 (weak), 0.15 (medium), 0.35 (strong). R square $\left(\mathrm{R}^{2}\right.$ ) based on criteria suggested by Cohen (1988) is 0.02 (weak), 0.13 (moderate) and 0.26 (substantial). $\mathrm{Q}^{2}$ for latent variable organizational citizenship behavior must greater than zero to indicate that this construct has predictive relevance (Hair et al., 2017).

\section{Measurement Scales}

All items used in the questionnaire were based on a Likert scale ranging from "strongly disagree (1)" to "strongly agree (7)". Supervisor support was measured by eight items adapted from Baloyi et al. (2014). Six items of co-worker support questionnaire were adapted from (Yang et al., 2015). Four items of organizational commitment questionnaire were adapted from organizational commitment literature (Colakoglu et al., 2010).

\section{Result}

\section{Profile of Respondents}

In term of the respondent profile, most of the respondents were female (68.4\%), aged between $38-47$ years (42.8\%), non-executive (60.4\%), and a monthly salary of between RM 2500 to RM 3999 (24.8\%).

Table 1: Profile of Respondent

\begin{tabular}{lll}
\hline Profile & Frequency & Percent (\%) \\
\hline Gender & & \\
Female & 171 & 68.4 \\
Male & 79 & 31.6 \\
\hline Age & & \\
Below 27 years old & 20 & 8.0 \\
28-37 years old & 88 & 35.2 \\
38-47 years old & 107 & 42.8 \\
More than 47 years old & 35 & 14.0 \\
& & \\
\hline Group & & \\
Executive & 99 & 39.6 \\
Non-executive & 151 & 60.4 \\
& & \\
\hline Salary & & \\
RM 1000-RM2499 & 77 & 30.8 \\
RM 2500-RM3999 & 62 & 24.8 \\
RM4000-RM5499 & 40 & 16.0 \\
RM5500-RM7000 & 34 & 13.6 \\
More than RM7000 & 37 & 14.8 \\
& & \\
\hline
\end{tabular}

\section{Measurement Model Analysis}

Measurement model analysis was done to ensure the validity and reliability of each item and construct. 


\section{Reliability Analysis}

In term of reliability, factor loading values for each item in independent variable (supervisor support is and so-worker support) are between 0.763-0.852 (supervisor support) and 0.8590.880 (co-worker support) and dependent variable is between 0.738-0.899 (organizational commitment) are higher than 0.708 which indicate that the measurement of the construct model had met its reliability criteria (Hair et al., 2017). The output values of Variance Inflation Factor (VIF) between independent variables (supervisor support and co-worker support) and dependent variable (organizational commitment) are 1.404 which lower than 5.0 indicated that the constructs were free from serious collinearity problems (Hair et al., 2017). The result for reliability is shown in Table 2 and Table 3 below:

Table 2: Factor Loading of the Instruments

\begin{tabular}{|l|l|}
\hline Construct/ Item & $\begin{array}{l}\text { Factor loading } \\
<0.708\end{array}$ \\
\hline Supervisor support & 0.769 \\
SS1 Quick corrective action. & 0.852 \\
SS2 Enough time to practice the skills & 0.763 \\
SS3 Clear instructions & 0.818 \\
SS4 Holds regular meetings/consultations & 0.813 \\
SS5 Give feedback tactfully & 0.809 \\
SS6 Praise when do a job well & 0.823 \\
SS7 Trust. & 0.828 \\
SS8 Proud & \\
\hline Co-worker support & 0.878 \\
CS1 Assist in dealing with crisis situations at work. & 0.859 \\
CS2 Being helpful & 0.896 \\
CS3 Always be involved in working. & 0.875 \\
CS4 Share their knowledge & 0.869 \\
CS5 Listening to problem related to work. & 0.880 \\
CS6 Give encouragement & \\
\hline Affective Commitment & 0.855 \\
OC1This organization means a lot & 0.899 \\
OC2 Feel like "part of the family" in my organization. & 0.863 \\
OC3 Feel a strong sense of "belonging" to my organization. & 0.738 \\
OC4 The problems of this organization seem to be my & \\
problems. &
\end{tabular}

Source: Authors calculation on Smart-PLS software

Table 3: Variance Inflation Factor (VIF) of the Instrument

\begin{tabular}{|l|l|l|l|}
\hline Construct & SS & CS & OC \\
\hline Supervisor Support (SS) & & & 1.404 \\
\hline Co-worker support & & & 1.404 \\
\hline $\begin{array}{l}\text { Organizational } \\
\text { Commitment (OC) }\end{array}$ & & & \\
\hline
\end{tabular}

Source: Authors calculation on Smart-PLS software 


\section{Convergent and Discriminant Validity}

Table 4 shows the result of convergent and discriminant validity analysis. For convergent validity, the value of Average Variance Extracted (AVE) which exceeded 0.5 indicated that the constructs meet the acceptable level of convergent validity (Hair et al., 2017). The Composite Reliability (CR) values for each construct are greater than 0.70 indicate that the internal consistency for the research instrument was high (Hair et al., 2017). Furthermore, the findings of discriminant validity using Heterotrait-Monotrait Ration (HTMT) for each construct is less than 0.85 (Clark \& Watson, 1995; Henseler et al., 2015), so the study construct has met the prescribed discrimination validity criteria (Barclay et al., 1995; Henseler et al., 2009). Therefore, this statistical result confirms that the constructs have met the acceptable standards of validity and reliability analysis.

Table 4: Convergent and Discriminant Validity Analysis

\begin{tabular}{l|llllll} 
CONSTRUCT & AVE & CR & CA & SS & CS & OC \\
\hline SS & 0.656 & 0.938 & 0.925 & & & \\
CS & 0.768 & 0.952 & 0.940 & 0.575 & & \\
OC & 0.707 & 0.906 & 0.862 & 0.651 & 0.532 &
\end{tabular}

Source: Authors calculation on Smart-PLS software

\section{Structural Model Analysis}

\section{Results on the Hypotheses}

The research hypotheses of Smart-PLS routes have shown that supervisor support has a positively correlated with organizational commitment $(\beta=0.468 ; t=8.566)$, thus $H 1$ is supported. Second, co-worker support positively correlated with organizational commitment $(ß=0.241, t=3.673)$. Thus, $H 2$ is supported. This result shows that management support (supervisor and co-worker) act as an important predictor on organizational commitment.

Table 5: Result on Hypotheses

\begin{tabular}{|c|c|c|c|c|c|c|}
\hline Hypotheses & $\begin{array}{l}\text { Path } \\
\text { coefficient } \\
\text { (ß) }\end{array}$ & $\begin{array}{l}\mathrm{t}- \\
\text { statistic }\end{array}$ & $\begin{array}{l}P \\
\text { value }\end{array}$ & \multicolumn{2}{|c|}{$\begin{array}{l}\text { Confidence } \\
\text { interval }\end{array}$} & Result \\
\hline $\begin{array}{l}\text { H1: supervisor support } \\
\text { significantly related to } \\
\text { organizational commitment }\end{array}$ & 0.468 & 8.566 & 0.000 & 0.339 & 0.565 & $\begin{array}{l}\mathrm{H} 1 \\
\text { accepted }\end{array}$ \\
\hline $\begin{array}{l}\text { H2: co-worker support } \\
\text { significantly related to } \\
\text { organizational commitment }\end{array}$ & 0.241 & 3.673 & 0.000 & 0.120 & 0.378 & $\begin{array}{l}\mathrm{H} 2 \\
\text { accepted }\end{array}$ \\
\hline
\end{tabular}

Source: Authors calculation on Smart-PLS software

The combined effect of the exogenous variables on endogenous variables was measured by $\mathrm{R}^{2}$ value. In this study, the effect of supervisor and co-worker support on organizational commitment is substantial (39.8\%). Furthermore, bootstrapping and blindfolding procedures were conducted to measure the effect size $\left(f^{2}\right)$ and predictive relevance $\left(Q^{2}\right)$. The result from the effect size $\left(f^{2}\right)$ test reveals that supervisor support gives a medium impact towards organizational commitment where the value was 0.259 which is below than 0.35 and coworker support gives a weak impact towards organizational commitment with 0.069 which is less than 0.15 (Hair et al., 2017). In addition, the results of testing the predictive relevance of 
reflective endogenous latent variable show that the $Q^{2}$ for organizational commitment was greater than zero which 0.204 and this suggests that this construct has predictive relevance (Hair et al., 2017).

\section{Discussion and Implication}

This study confirms that perceived organizational support does play as an important factor in organizational commitment. However, even though the path coefficient $\left(R^{2}\right)$ is high, new findings showed that the co-worker support has a weak effect size towards organizational commitment. This is because the support informally knows as courtesy (tolong-menolong) in Malaysia culture of social work (Aun et al., 2018). Moreover, Malaysian normally practices this courtesy culture in every aspect in life. Hence, this situation did not give an adequate impact on employees' commitment even though they receive the support from co-worker. Moreover, there are other factors that influence employee commitment on the organization such as a modern and comfortable working environment and demographic factors (NkhukhuOrlando et al., 2019).

The implication of this study can be divided into three major aspects: theoretical implication, the robustness of research methodology, and contribution to practical (organization). In term of theoretical implications, this study shows that the organizational support (Eisenberger, 1986) is in line with the results. An employee who received a prominent and efficient support from the organization give a positive respond which is show their commitment towards organization. The methodology of this study shows the selected questionnaires data exceeded a minimum standard of validity and reliability; this leads to a production of accurate findings. In regard of practical contributions, this study provides a chance for the higher management to provide sufficient support in accordance to increase their commitment on organization. To ensure that the objective is achieved, first: the organization must identify and give a proper and formal guideline that include scope and co-worker support program to the employees. This program which provides details regarding the teamwork, sharing ideas and who to ask help based on task scope and expertise.

\section{Limitation}

Limitations are also existed in this study. This study only focuses on government institutions only, therefore the findings of this study are not suitable to be generalized to other sectors or organizations. This study also uses cross-sectional study methods. Therefore, data is only collected once. The researcher recommends future studies to conduct longitudinal studies to see the effectiveness of support practices before and after employees receive such support. In addition, this study used purposive sampling as the organization adopts a confidentiality policy which in turn will create a bias in the answers given by the respondents. In future research, the researcher suggested that random sampling technique should be used to avoid bias element. Furthermore, future research should explore how perceived organizational support might influence another construct such as job satisfaction, employee service quality and performance.

\section{Conclusion}

This study measured the relationship between organizational support on affective commitment based on organizational support past literature. The measurement analysis and structural analysis confirmed that all the items used in this study satisfied the standards of 
validity and reliability analyses. Hypotheses analysis using the Smart-PLS software confirmed that both support from supervisor and co-worker positively related with affective commitment. This study further suggests that the ability of the management to provide and practice a proper technology and online support practices such as fully utilized the technology communication network and modern equipment to increase the effectiveness of support in organization among employees may lead to increase employees' behavior (e.g., turnover intention, citizenship behavior and employee performance). Therefore, this outcome may drive the organization to maintain and enhance organizational competitiveness in an era of the global economy.

\section{References}

Ahmed, I., Khairuzzaman, W., Ismail, W., Amin, S. M., Ramzan, M., \& Khan, M. K. (2012). Theorizing antecedents of Perceived Organizational Support: A literature review approach. Middle-East Journal of Scientific Research, 12, 692-698.

Ahmad, N.A., Sham, F.M, \& Ismail, A. (2021). Is perceived organizational support an antecedent of employee behaviour? International Journal of Human Resource Studies, 11(1), 351-365.

Andini, W., \& Parahyanti, E. (2019). Relationship between Perceived Organizational Support and Organizational Affective Commitment: Moderating Role of Psychological Contract Breach.

Aun, N. S., Akhir, N. M., \& Nofiah, N. A. (2018). Aplikasi konsep ta'awun dalam praktis kerja sosial di Malaysia (application on ta'awun concept in social work practice in Malaysia). Akademika, 88.

Baloyi, S., Van Waveren, C., \& Chan, K. Y. (2014). The role of supervisor support in predicting employee job satisfaction from their perception of the performancemanagement system: a test of competing models in engineering environments. South African Journal of Industrial Engineering, 25(1), 85-95.

Bayraktar O., \& Atac, C. (2018). The effects of industry 4.0 on human resources management globalization, institutions and socio-economic performance macro and micro perspectives. GmbH Publisher, 337-359.

Colakoglu, U., Culha, O., \& Atay, H. (2010). The effects of perceived organisational support on employees' affective outcomes: evidence from the hotel industry. Tourism and Hospitality Management, 16(2),125-150.

Creswell, J. W. (2014). Research design: qualitative, quantitative, and mixed methods I approaches. Fourth Edition. United States of America: Sage Publications, Inc.

Eisenberger, R., Stinglhamber, F., Vandenberghe, C., Sucharski, I. L., \& Rhoades, L. (2002). Perceived supervisor support: Contributions to Perceived Organizational Support and Employee Retention. Journal of Applied Psychology, 87(3), 565-573.

Eisenberger, R., Glenn, P., Malone, D., \& Presson, W. D. (2016). Optimizing perceived organizational support to enhance employee engagement. SHRM-SIOP Science of HR Series.

Eisenberger, R., Huntington, R., Hutchison, S., \& Sowa, S. (1986). Perceived organizational support. Journal of Applied Psychology, 71(31), 500-507.

Erdfelder, E., Faul, F., \& Buchner, A. (1996). GPOWER: A general power analysis program. Behavior Research Methods, Instruments, \& Computers, 28,1-11.

Hair, J. F. Jr., Hult, G. T. M., Ringle, C. M., \& Sarstedt, M. (2017). A Primer on Partial Least Squares Structural Equation Modeling. 2nd edition. Thousand Oaks, CA: Sage. 
Ibrahim, H. I., \& Mohamad, W., \& Shah, K. A.. (2020). Investigating Information and Communication Technology (ICT) Usage, Knowledge Sharing and Innovative Behavior among Engineers in Electrical and Electronic MNCs in Malaysia. Jurnal Pengurusan. 58,133 - 143. doi: https://doi.org/10.17576/pengurusan-2020-58-11

Henseler, J., Ringle, C. M., and Sinkovics, R. R. (2009), "The use of partial least squares path modeling in international marketing", in Sinkovics, R.R. and Ghauri, P.N. (Eds), Advances in International Marketing, Vol. 20, Emerald, Bingley, 277-320.

Ismail, I. R., June, M. L. P., \& Arshad, R. (2018). Effects of workplace incivility, negative affectivity and hurt feelings on coworker helping. Jurnal Pengurusan. 52, 33-45.

Jehanzeb, K., \& Bashir, N. (2013). Training and Development Program and its Benefits to Employee and Organization: A Conceptual Study. European Journal of Business and Management, 5, 243-252.

Kaur, S., \& Aneet. (2017). Perceived organizational support and affective commitment: a demographic analysis. IOSR Journal of Business and Management (IOSR-JBM), 19(1), 54-59. doi: 10.9790/487X-1901045459 www.iosrjournals.org

Kurtessis, J. N., Eisenberger, R., Ford, M. T., Buffardi, L. C., Stewart, K. A., Adis, C. S. (2015). Perceived organizational support: a meta-analytic evaluation of organizational support theory. Journal of Management. doi: 10.1177/0149206315575554

Morrar R., Arman, H., \& Mousa S. (2017). The fourth industrial revolution (industry 4.0): A social innovation perspective. Technology Innovation Management Review, 7(11), 1320.

Mobo, F. D., \& Rahmat, A. (2021). The impact of video conferencing platform in all educational sectors amidst Covid-19 pandemic. AKSARA: Jurnal IImu Pendidikan Nonformal, 7(1), 15-18. doi: http://ejurnal.pps.ung.ac.id/index.php/AKSARA/index

Malaysian Communications and Multimedia Commission MCMC. (2020). Internet Users Survey 2020. doi:https://www.mcmc.gov.my/skmmgovmy/media/General/pdf/IUS 2020-Report.pdf

Nkhukhu-Orlando, E., Brown, B., Wilson, D. R., Forcheh, N., Linn, J. G., \& Fako, T. T. (2019).The affective commitment of academics in a university in Botswana. International Journal of Educational Administration and PolicyStudies, 11(2), 12-19.

Ogbodoakum, N., Ayub, A. F. M., \& Abiddin, N. Z. (2020). The role of peer support, superior support, training self-efficacy, training needs and opportunity to use on readiness to participate in training among civil servants in Nigeria. International Journal of Academic Research in Business and Social Sciences, 10(12), 868-887.

Putri, K., Haryadi, H., \& Anggraeni, A.I. (2018). The influence of POS on employee performance with job satisfaction as a mediator. Journal of Accounting Management and Economics,20(1), 18-29

Pfano, M., \& Beharry, A. (2016). The effect of modern office technology on management performance: Durban Westville. Problems and perspectives in management, 14, 376384.

Reshma, P., Aithal, S., \& Acharya, S. (2015). An Empirical Study on Working from Home: A Popular E-Business Model. International Journal of Advance and Innovative Research, $2(2-1), 12-18$.

Raisiene, A. G., Rapuano, V., Varkulevici, K., \& Stachova, K. (2020). Working from home who is happy? A survey of lithuania's employees during the covid-19 quarantine period 2. Sustainability, 12, 5332; doi:10.3390/su12135332 
Rabbani, S. H., Akram, J., Habib, G., \& Sohail, N. (2017). Supervisory support on the organizational commitment: Role of power distance in the manufacturing sector of Pakistan. European Journal of Business and Management, 9(22), 1-12.

Ringle, C. M., Wende, S., \& Becker, J. M. (2015). SmartPLS 3. Bönningstedt: SmartPLS. Retrieved from https://www.smartpls.com

Roochmi, A., \& Hidayat, E. (2018). The mediating role of affective commitment in perceived organizational support and readiness for change. Advances in Social Science, Education and Humanities Research, 229, 785-795.

Sekaran, U., \& Bougie, R. (2010). Research methods for business: A skill building approach (5th ed.). West Sussex, UK: John Wiley \& Sons Ltd.

Sima V., Gheorghe, I. G., Subi, C. J., \& Nancu, D. (2020). Influences of the Industry 4.0 revolution on the human capital development and consumer behavior: a systematic review. Sustainability, 12, 4035; doi:10.3390/su12104035

Tajuddin, N., Arshad, R., Shamsudin, R. M., \& Yunan, Y. Y. M. (2019). Hubungan Orientasi Matlamat, Pemantauan Kendiri Dan Tingkah Laku Kerja Inovatif: Komitmen Afektif Sebagai Pengantara. Journal of Management, 56.

56,47 - 57. doi: https://doi.org/10.17576/pengurusan-2019-56-05

Ting, D., Carin, L., Dzau, V., \& Wong, T. Y. (2020). Digital technology and COVID-19. Nature Medicine. Retrieved at https://www.nature.com/articles/s41591-020-0824-5.pdf

Uzun, T. (2018). A Study of correlations between perceived supervisor support, organizational identification organizational citizenship behaviour and burnout at schools. European Journal of Educational Research, 7 (3), 501-511.

Cascio, W., \& Montealegre, R. (2016). How Technology Is Changing Work and Organizations. Annual Review of Organizational Psychology and Organizational Behaviour, 349-375.

Yahaya, J., Ibrahim, S. R., Hamdan, A., Deraman, A., \& Jusoh, Y. Y. (2018). Model Kesediaan Pelaksanaan Teknologi Maklumat untuk Perusahaan Kecil dan Sederhana Ke Arah Era Revolusi Industri 4.0. Journal of Management, 54. 